DOI: $10.14451 / 2.128 .7$

\title{
ЗНАЧЕНИЕ КАТЕГОРИИ «ЗАКОННЫЕ ИНТЕРЕСЫ» ДЛЯ ЗАЩИТЫ ИМУЩЕСТВЕННЫХ ПРАВ АВТОРОВ И ИНЫХ ПРАВООБЛАДАТЕЛЕЙ
}

\author{
(C) 2019 Данилов Юрий Сергеевич \\ Генеральный директор ООО «ЮСД Групп» \\ 129110, г. Москва, пр-т. Олимпийский, д. 16, стр. 5 \\ E-mail:info@usdgroup.ru
}

Статья посвящена анализу имущественных интересов авторов и иных правообладателей, разработке категории «законные интересы» применительно к вопросам охраны и защиты принадлежащих им исключительных и иных имущественных прав.

В статье обосновывается вывод о том, что понятие «законный интерес» несет особую смысловую и регулятивную нагрузку, позволяя сочетать защиту интересов правообладателей с возможностью наиболее гибкого толкования правовых норм, закрепляющих связанные с такими интересами субъективные права и юридическую ответственность.

Автор отмечает, что понятие «законный интерес» может использоваться в качестве системообразующего при рассмотрении вопросов возмещения вреда, причиняемого авторам и иным правообладателям в случае нарушений принадлежащих им исключительных и иных имущественных прав.

Ключевые слова: произведение, автор, авторское право, смежные права, правообладатель, исключительное право, нарушение авторских прав, защита авторских прав, нарушение исключительного права, информационный посредник, информационные ресурсы, убытки, возмещение убытков.

На протяжении последних десятилетий происходило интенсивное развитие законодательства о защите исключительных и иных имущественных прав авторов и других обладателей авторских и смежных прав, сопровождавшееся изменением правовых подходов и закрепляющих их правовых норм, в том числе неоднократной модификацией положений о компенсации за нарушения исключительных прав.

Как отмечает Л.А. Новоселова, развитие законодательства, регламентирующего на современном этапе вопросы, связанные с интеллектуальной собственностью, приобрело «многовекторный характер» [7, С. 3], учитывающий интересы различных сторон общественных отношений, наличие сложных внутренних системных противоречий и необходимость поиска новых решений в условиях продолжающегося технологического развития.

Однако происходящие изменения в части защиты исключительных и иных имущественных прав на произведения и объекты смежных прав, как правило, основывались на попытках эмпирического поиска оптимальных вариантов борьбы с нарушениями и не сопровождались своевременной разработкой теоретических оснований для вносимых в законодательство изменений.
Отсутствие базовых принципов, которые должны лежать в основе обеспечения защиты прав и законных интересов авторов и правообладателей, приводит к непоследовательному развитию и усложнению правового регулирования, а также препятствует формированию устойчивой и единообразной судебной практики.

В частности, в недостаточной степени анализировались имущественные интересы авторов и иных правообладателей, разработка данной категории применительно к вопросам охраны и защиты имущественных прав и законных интересов авторов и иных обладателей исключительных прав практически не осуществлялась.

Интерес участника правоотношения не всегда возможно обеспечить только за счет предоставления такому участнику определенного субъективного права [10, С. 362], что обусловило широкое использование конструкции «права и законные интересы» в законодательных актах различной отраслевой принадлежности. При этом термин «законный интерес» в законодательстве не определяется, содержание данного термина составляет предмет научных дискуссий в теории права [9, С. 35; 1, С. 56].

Законные интересы, наряду с субъективными правами, признаются самостоятельными 
объектами правовой охраны и защиты [10, С. 362]. Так, статья 3 Гражданского процессуального кодекса Российской Федерации и статья 4 Арбитражного процессуального кодекса Российской Федерации предусматривают возможность обращения за защитой как нарушенного или оспариваемого права, так и законного интереса, при этом правильным представляется мнение о том, что «охраняемый законом интерес порождается именно нормой материального права, процессуальная норма служит средством его защиты и обеспечения принудительного удовлетворения» [3, C. 95].

Необходимость признания наряду с субъективными правами существования также законных интересов в качестве более обширной по своему охвату правовой категории обусловлена тем, что разнообразие интересов граждан и юридических лиц делает невозможным полное и своевременное отражение таких интересов, а также учет всех особенностей возникающих на практике ситуаций в правовых нормах, закрепляющих конкретные субъективные права.

Многообразие возможных интересов, обусловленное динамизмом и сложностью социальных связей, общественных отношений, возникающих между субъектами гражданского права в современном обществе, влиянием факторов индивидуальности и случайности не позволяет обеспечить выражение таких интересов в форме субъективного права, требует более широких форм их выражения и защиты. Как справедливо отмечает Г.В. Мальцев: «не все социальные интересы, находящиеся под защитой права, могут и должны выступать в форме субъективного права» [6, С. 364].Такая ситуация для сферы гражданского права обусловлена, в частности, тем обстоятельством, что «область дозволенного не исчерпывается одними лишь субъективными правами ... в конструкции охраняемого законом интереса объединяются в единое целое юридически защищенный интерес и правовая возможность удовлетворить его» [11, С. 88].

В случае если интересы субъектов права не противоречат принципам права и установленным нормативным предписаниям, они могут признаваться законными и для их защиты могут применяться те же способы, которые предусматриваются для защиты наиболее тесным образом связанных с ними субъективных прав.

Таким образом, охрана законного интереса может обеспечиваться независимо от наличия или отсутствия его непосредственного выражения в форме субъективного права, выступая в качестве предоставляемой и гарантируемой государством правовой возможности, включая дозволение, разрешение, а также отсутствие запрета для осуществления действий и предъявления требований, направленных на получение определенных материальных или нематериальных благ. Государство предоставляет обладателю такого законного интереса право обращаться за его защитой: «Под законным интересом следует понимать стремление субъекта пользоваться определенным социальным благом и в некоторых случаях обращаться за защитой к компетентным органам в целях удовлетворения не противоречащих нормам права интересов, которое в определенной степени гарантируется государством в виде юридической дозволенности, отраженной в объективном праве либо вытекающей из его общего смысла» [10, С. 363-364].

Законный интерес может рассматриваться как предоставление его обладателю правовой возможности в отношении получения, обладания и защиты материальных и нематериальных благ, включая возможность обращения в установленном порядке к уполномоченным государственным органам для защиты. Законный интерес как самостоятельный объект правовой охраны позволяет его обладателю обращаться за его защитой независимо от того обстоятельства, может ли его обладатель требовать от других лиц какого-либо определенного поведения, что является характерной чертой субъективного права и коррелирующей ему юридической обязанности, хотя несомненно, что законные интересы по мере их выявления и развития правового регулирования могут служить основой для законодательного закрепления определенных субъективных прав [5, С. 17] или их последовательной корректировки.

Так, обладатель исключительных прав на произведение в некоторых случаях оказывается лишен возможности привлекать к ответственности лиц, действия которых привели к нарушению его прав, например, граждан или некоммерческие организации, которые осуществляли использование произведений, но при этом не знали о нарушении прав на такие произведения. Рассмотрение данной ситуации с точки зрения субъективного права и связанной с ним юридической обязанности приводит к тому, что такие лица не несут ответственности за незаконное ис- 
пользование произведений, нарушение прав на них. В частности, абзац первый пункта 3 статьи 1250 Гражданского кодекса Российской Федерации устанавливает, что меры ответственности за нарушение интеллектуальных прав подлежат применению только при наличии вины нарушителя, если ГК РФ не предусматривается иное.

В то же время анализ данной ситуации с учетом законного интереса правообладателей в получении соразмерного вознаграждения за использование произведений позволяет прийти к выводу о том, что даже в случае невиновного, но тем не менее незаконного использования правообладатель должен иметь возможность получить такое вознаграждение, в том числе в форме выплаты компенсации, соразмерной обычно получаемому в аналогичных случаях вознаграждению. Таким образом, подход, основанный на признании необходимости удовлетворения законных имущественных интересов правообладателей, позволяет исключить случаи, в которых правообладатели оказываются лишены возможности возместить причиненный им имущественный вред за счет лиц, действия которых привели к нарушению принадлежащих им прав, в том числе при отсутствии вины таких лиц в совершенном нарушении.

Понятие «законный интерес» может использоваться в качестве системообразующего при рассмотрении вопросов возмещения вреда, причиняемого авторам и иным правообладателям при нарушениях принадлежащих им исключительных и иных имущественных прав.

С учетом особенностей отраслевой принадлежности положений об охране авторских и смежных прав законные имущественные интересы авторов и иных правообладателей, которые призвано гарантировать гражданское право, могут быть охарактеризованы как совокупность возможностей распоряжения правами на произведения и объекты смежных прав, получения вознаграждения за их использование, возмещения вреда, причиняемого нарушениями исключительных и иных имущественных прав, а также реализации права на получение дополнительного, компенсационного и иного вознаграждения в случаях, предусмотренных законом. Указанные возможности могут реализовываться как собственными действиями заинтересованного лица, в том числе в результате вступления в договорные отношения, использования технических средств защиты, получения вознаграж- дения от организаций, управляющих имущественными авторскими и смежными правами на коллективной основе, так и путем обращения за защитой своих законных интересов в судебном, административном и ином установленном законодательством порядке.

При этом нельзя согласиться с тем, что в законных интересах отражаются менее значимые и существенные потребности, а также с каким-либо противопоставлением законных интересов, с одной стороны, и субъективных прав, с другой. Субъективные права и законные интересы связаны друг с другом, имеют единую направленность, позволяют заинтересованным лицам удовлетворять и отстаивать их собственные интересы, в том числе связанные с обладанием определенными материальными и нематериальными благами и их защитой.

Законный интерес находит свою реализацию через участие его обладателя в общественных отношениях, регулируемых правом, которое, в свою очередь, закрепляет определенные субъективные права и юридические обязанности сторон таких отношений. Как отмечал, в частности, Н.С. Малеин: «наделение правом означает обеспеченную государством возможность удовлетворения интересов... В этом смысле интерес выступает объектом правовой охраны» [2, С. 43]. С.Н.Братусь, считая интерес внешним по отношению к субъективному праву, не входящим в его состав фактором, также признавал, что по отношению к субъективному праву интерес является его целью и предпосылкой [8, С. 108; 4, С. 73].

Понятие «законный интерес», как представляется, несет особую смысловую и регулятивную нагрузку, позволяя осуществлять защиту интересов правообладателей с возможностью наиболее гибкого толкования правовых норм, закрепляющих связанные с такими интересами субъективные права и юридическую ответственность, и способствуя выработке новых подходов к решению задач защиты авторских и смежных прав.

Так, существует необходимость изменения концептуального подхода к определению правовой природы компенсации за нарушение исключительного права при незаконном использовании произведений и объектов смежных прав. Указанная компенсация должна рассматриваться не только в качестве меры ответственности, что исключает ее применение при отсутствии 
вины нарушителя, кроме случаев осуществления им предпринимательской деятельности (п. 3 ст. 1250 ГК РФ), но также в качестве особого способа защиты имущественных интересов, в частности, возмещения имущественного вреда, причиненного правообладателю и подлежащего возмещению независимо от вины нарушителя.

В связи с этим в зависимости от целевой направленности возможно выделить основную компенсацию, представляющую собой возмещение вреда, соразмерное обычно получаемому вознаграждению за использование объекта авторского или смежного права при отсутствии доказательств причинения нарушением вреда в большем размере, и дополнительную компенсацию, взыскиваемую с нарушителей в качестве меры ответственности только при наличии вины для решения задач общей и частной превенции.

Определение размера основной компенсации, взыскиваемой с нарушителя в целях возмещения вреда (предполагаемых убытков), должно осуществляться без учета наличия умысла на совершение правонарушения или вины нарушителя в какой-либо иной форме. Отсутствие вины нарушителя не должно освобождать его от выплаты такой компенсации или служить основанием для снижения ее размера, поскольку основная компенсация должна служить исключительно целям возмещения вреда, причиняемого правообладателям вследствие нарушения.

Размер такой компенсации может определяться по выбору правообладателя в соответствии с положениями статьи 15 ГК РФ (в зависимости от причиненных убытков, полученного нарушителем дохода и т.д.) либо с учетом дополнительных факторов. К числу таких факторов могут быть отнесены, в частности, сведения о доходах, получаемых другими правообладателями при отсутствии нарушений исключительных прав в сопоставимых случаях, оценка рыночной стоимости прав на соответствующее использование произведений и объектов смежных прав, сведения о затратах, понесенных правообладателем на создание произведения или объекта смежных прав либо приобретение исключительных прав на их использование, и другие обстоятельства, учитываемые в силу указания закона или по усмотрению суда.

При взыскании дополнительной компенсации должны учитываться степень вины нарушителя и размер убытков, которые могли быть причинены в результате нарушения исключи- тельного права на момент истребования компенсации или могут возникнуть, или быть выявлены в дальнейшем вследствие допущенного нарушения исключительного права, а также неоднократное совершение ранее нарушений исключительных прав, принадлежащих данному правообладателю или иным лицам, при наличии вины нарушителя в их совершении.

Суд должен иметь возможность с учетом обстоятельств конкретного дела снижать размер взыскиваемой дополнительной компенсации по своему усмотрению на основе принципов разумности и справедливости для исключения случаев присуждения компенсаций, очевидным образом не соразмерных последствиям нарушений, и иных случаев применения законодательных положений вопреки их назначению и с причинением несоразмерных убытков одной из сторон гражданско-правовых отношений.

Именно рассмотрение права на получение компенсации за нарушение исключительных прав в качестве средства удовлетворения законных интересов правообладателя позволяет обосновать необходимость широкого судебного усмотрения при определении размера такой компенсации с учетом обстоятельств каждого конкретного случая.

Законный интерес, как и субъективное право, должен обеспечиваться возможностью защиты со стороны государства при условии правомерности и обоснованности таких интересов и выдвигаемых на их основе требований, что, в свою очередь, позволяет использовать анализ наличия законного интереса и его содержания как основу для выявления, предотвращения и пресечения случаев злоупотребления правами со стороны отдельных недобросовестных лиц, в том числе при истребовании несоразмерных компенсаций за нарушения исключительных прав.

Наряду с необходимостью обеспечения эффективного воздействия на нарушителей путем взыскания с них компенсаций за нарушения исключительных прав существует также настоятельная необходимость обеспечить получение правообладателями вознаграждения в тех случаях, когда его выплата предусматривается непосредственно положениями ГК РФ. Для реализации права на вознаграждение, установленного законом (ст. 1245 , п. 3 ст. 1263, ст. 1293, п. 2 ст. 1295 или ст. 1326 ГК РФ), необходима разработка специального порядка защиты прав, ос- 
нованного на общих положениях гражданского законодательства.

В указанных случаях речь идет о взыскании вознаграждения в размере, определяемом в установленном законом порядке, между сторонами отсутствуют договорные отношения, а сама по себе невыплата приводит к причинению автору или иному правообладателю убытков в объеме неполученного им вознаграждения, не влияя при этом на условия использования произведений или объектов смежных прав и на доходы, получаемые от такого использования. Задержка выплаты вознаграждения при этом может компенсироваться за счет взыскания специальной неустойки (пени), которая может быть предусмотрена законодательством по аналогии с установленной ст. 395 ГК РФ возможностью истребования процентов на сумму долга в случае неправомерного удержания денежных средств.

Важнейшее значение для использования произведений и объектов смежных прав на современном этапе приобрела деятельность «информационных посредников», обеспечивающих функционирование информационных ресурсов в сети Интернет и осуществление обмена данными между ее пользователями. Информационные посредники обладают возможностями наиболее оперативного воздействия на нарушителей. При этом необходимо разграничивать случаи осуществления деятельности, предусмотренной положениями ст. 1253.1 ГК РФ, для которых устанавливаются ограничения ответственности информационных посредников, от случаев опосредованного (косвенного) использования объектов авторских и смежных прав, осущест- вляемого, в частности, социальными сетями и иными информационными ресурсами в сети Интернет, получающими доходы от размещения пользователями материалов на таких информационных ресурсах, в том числе включающих объекты авторских и смежных прав.

Такие лица в целях защиты имущественных интересов правообладателей могут привлекаться к солидарной ответственности за нарушения исключительных, в том числе при отсутствии вины на началах предпринимательского риска в соответствии с положениями п. 3 ст. 1250 ГК РФ, либо суду должна быть предоставлена возможность возложения на них специальной ответственности в форме частичной компенсации причиненных правообладателю убытков в размере, определяемом с учетом, в частности, таких факторов, как добросовестность поведения, принятие мер для пресечения и предотвращения нарушений, доход, получаемый в результате осуществления деятельности, способствовавшей нарушению исключительных прав.

Изложенный выше комплексный подход позволит авторам и иным правообладателям в наиболее полной мере защищать их имущественные интересы в случае нарушений принадлежащих им исключительных и иных имущественных прав, возмещая причиняемые им имущественные потериза счет нарушителей, недобросовестных плательщиков и лиц, извлекающих доходы от осуществления деятельности, связанной с нарушениями авторских и смежных прав, в том числе в условиях развития новых информационно-телекоммуникационных технологий.

\section{Библиографический список}

1. Бартов А.А. Соотношение субъективных прав и законных интересов // Пробелы в российском законодательстве. 2010. № 3. С. 56-59.

2. Ильина И.Ю. О правовой категории охраняемого законом интереса в контексте конфликта интересов участников гражданских правоотношений // Государственная служба и кадры. 2018. № 3. С. 42-46.

3. Кляус Н.В. Понятие охраняемого законом интереса как предмета судебной защиты в гражданском судопроизводстве // Вестник Омского университета. 2002. № 2. С. 92-95.

4. Козлов М. А. Субъективное право и охраняемый законом интерес как предметы судебной защиты // Журнал российского права. 2008. № 3. С. 69-77.

5. Малько А.В., Терехин В.А. Субъективные права, свободы и законные интересы личности как самостоятельные объекты судебной защиты // Ленинградский юридический журнал. 2010. № 4. С. 7-18.

6. Мальцев Г.В. Социальные основания права. Москва. 2007. 800 с.

7. Новоселова Л.А., Рожкова М.А. Интеллектуальная собственность: некоторые аспекты правового регулирования: монография. Москва. 2014. 128 с. 
8. Пономаренко И.Е. Структура правового интереса: теоретико-правовой аспект // Вестник ЮУрГУ. Серия «Право». 2017. Т.17. № 4. С. 107-112.

9. Солодовниченко Т.А. Законный интерес: проблемы понимания и соотношения с субъективным юридическим правом и юридической обязанностью // Вестник Омской юридической академии. 2016. № 3.- С. 35-39.

10. Субочев В.В. Законные интересы // В изд.: Проблемы теории государства и права / Под ред. А.В. Малько.М.: Юрлитинформ, 2012.- С. 362-380.

11. Ульянов А.В. О гражданско-правовой охране интересов субъекта правоожиданий // Актуальные проблемы российского права. 2017. № 8 (81).-С. 87-98. 